\title{
Big GAAP-Little GAAP \\ Does One-Size-Fits-All Still Work?
}

Paula Morris, (Email: pmorris@kennesaw.edu), Kennesaw State University

Jane Campbell, (Email: jcampbel@kennesaw.edu), Kennesaw State University

\begin{abstract}
Initiatives for developing Generally Accepted Accounting Principles for private/smaller businesses have surfaced in the United States and internationally. This paper explores those initiatives and identifies common elements and problems in these efforts.
\end{abstract}

\section{INTRODUCTION}

¿

$\mathrm{n}$ the United States (US), the accounting profession historically has developed and promulgated one set of generally accepted accounting principles (GAAP) for businesses. Periodically some accountants, as well as users of financial information, have called for a second set of accounting principles, one addressed to the needs of smaller and/or privately held businesses. This discussion has frequently been referred to as "Big GAAPLittle GAAP." The one-size-fits-all approach to accounting principles, however, has prevailed over time. With the change in the regulatory environment in the US as a result of Enron, WorldCom, and a host of other financial reporting scandals, we again see active discussion in the US of an alternative set of accepted accounting standards for small businesses. In the international accounting community, there is also consideration of differential accounting for small and medium sized entities. As yet it is not clear what direction this differential accounting should take. In this paper, we present the history of the development of GAAP in the US and a description of the current discussions, in the US as well as internationally, on alternative GAAP for smaller and/or privately held entities. In addition we discuss common elements and problems in these efforts.

\section{THE EVOLUTION OF ACCOUNTING STANDARDS IN THE US}

The first organization involved in the development of accounting principles in the US was the American Institute of Accountants (AIA), a private professional organization of accountants. In the early part of the twentieth century, the AIA cooperated with various interested groups, the Federal Trade Commission, the New York Stock Exchange, and the Federal Reserve Board, in this endeavor (Davidson 111). However, there was no mandate for GAAP until the stock market crash of 1929. At that point, the Congress of the United States created the Securities and Exchange Commission (SEC) and granted it the authority to promulgate GAAP for entities falling under its jurisdiction. The SEC, however, delegated the responsibility for making GAAP to the accounting profession through the AIA.

The AIA thrived. Eventually, it changed its name to the American Institute of Certified Public Accountants (AICPA). It gradually expanded the scope of its activities related to the accounting profession, with its Accounting Principles Board making GAAP and various other committees making professional performance standards for CPAs.

After many years, in the early 1970's, the profession decided it was time for change. Many financial statement users as well as the US government were concerned that the AICPA played conflicting roles as the maker of GAAP as well as the standard setter for auditing standards. So in 1973, the Financial Accounting Standards Board (FASB) was created to establish GAAP in the US. Although the SEC retained its legislative mandate to make GAAP for publicly traded companies, it continued and continues today to recognize the FASB as "the authoritative support" for GAAP. In addition, the accounting profession in the US has recognized and continues to recognize the FASB as the first tier maker of GAAP for all business entities (AICPA, Codification, SAS 69, AU 411.18). 


\section{THE DEBATE OVER ONE-SIZE-FITS-ALL ACCOUNTING IN THE US}

For years accountants serving smaller and/or privately held companies have expressed dissatisfaction with the FASB and its pronouncements. As early as 1974, the AICPA issued a discussion paper related to GAAP for smaller and/or closely held businesses (AICPA Report of the Committee 3). Periodically over the last 30 year period, the topics of Big GAAP-Little GAAP and Standards Overload have reared their heads. Concerns have ranged from excessive disclosure requirements to excessive complexity in the rules and their application. But every time the issues have come under discussion in the US, the profession always has decided that, with a few exceptions, accounting is accounting, no matter the size, no matter the user. The profession consistently has supported the concept of general purpose financial statements which would meet the need of "various potential users of that reporting for making investment and credit decisions" (AICPA Private Company Discussion 2). three factors:

Currently in the US, Big GAAP-Little GAAP is a popular topic again. Why? Renewed interest stems from

- $\quad$ Continuing concern about excessive disclosure and complexity,

- $\quad$ A stricter regulatory environment over financial reporting in the US, and

- The convergence of accounting standards issued by the FASB and the International Accounting Standards Board (IASB).

In the summer of 2002, the US Congress passed the Sarbanes-Oxley Act (SOX) in response to the financial scandals at Enron, WorldCom and a host of other publicly traded companies. SOX has created renewed interest in the Big GAAP-Little GAAP issue for several reasons. First, SOX changed the FASB funding from private contributions to public funding (Swift 11). This funding filters to the FASB through the government from "accounting support" fees paid by publicly traded companies to the SEC (SOX sec.109). Second, the FASB has developed "effective formal and informal working relationships with the [Public Companies Accounting Oversight Board] PCAOB" (Swift 11). These new relationships between the FASB and the SEC and the FASB and the PCAOB create a concern that the FASB will be more responsive to regulatory pressures regarding accounting for publicly traded companies than the needs of privately traded and/or smaller businesses. According to the AICPA Private Company Financial Reporting Task Force, there are approximately 17,000 publicly traded corporations in the US but 4.9 million private corporations (AICPA Task Force Report 4). The alignment of the FASB with the regulation of public companies could adversely affect accounting for the myriad of privately held entities.

The other factor contributing to the renewed discussion of the Big GAAP-Little GAAP issue is that the FASB and the IASB are "working actively together in pursuit of international convergence" (Swift 12). Since the IASB is considering separate standards for small and medium-sized entities, convergence on these standards, as well, would seem likely.

There are many supporters of the creation of a separate GAAP for smaller and/or privately held businesses. In the current accounting environment, there are some who previously opposed "Little GAAP" that now support it. Bill Balhoff, accounting activist, former AICPA council member and FASB advisory council member, typifies this position. For years, he "defended" the concept of a single set of GAAP for all companies - big-little, public-private. But based upon the recent actions of the FASB, the creation of the PCAOB, and the gradual movement to aligning with international standards, he contends that it is time for a split in GAAP (Cheney 2).

The Pennsylvania Institute of CPAs (PICPA) issued a "White Paper" in 2003 which supports separate accounting standards for private companies. In describing this "White Paper" in their article, Wallace and Wortmann note factors which suggest a need for developing different standards for nonpublic companies. These include:

- $\quad$ Fundamental changes in GAAP and the nature of doing business

- $\quad$ Harmonization with international standards

- Increased level of business complexity to compete in capital markets

- Movement towards fair value accounting. 
The "White Paper," according to Wallace and Wortmann, suggests fundamental differences in objectives for financial reporting for private versus public companies. For private companies, the overriding objective is to provide information for stewardship while, for public companies, it is to provide information for valuation. In fact, the "White Paper" proposes that a separate standard setting body should make GAAP for private companies. This mechanism would allow for adequate participation of those companies, their accountants, and the users of their financial statements in the due process procedures of making GAAP.

Of course there is also opposition to the creation of Big GAAP-Little GAAP. Some detractors hold that fair financial presentation is fair financial presentation, irrespective of public accountability. "The basic financial statement assertions - existence or occurrence, completeness, rights and obligations, valuation and allocation, and presentation and disclosure - are not different" (Wallace). Others believe that smaller entities already have an acceptable option: use of another comprehensive basis of accounting (OCBOA) such as tax basis or cash basis accounting (Wallace). In his article, Cheney concludes that the FASB already makes allowances for omitting disclosure for private companies. He suggests that a separate set of GAAP raises too many questions such as: who would make the standards, how would the international community accept the alternate GAAP, would we lose comparability, what would happen when a company goes public (Cheney 2,3). In addition, if a complex standard is not relevant to or material for an entity, the company will not concern itself with implementing that standard, thus making the notion of alternate GAAP moot.

Another, perhaps, more significant issue is: Would dual GAAP result in a two tier system-Lesser GAAP vs. Better GAAP, rather than Little GAAP vs. Big GAAP? Perhaps companies opting to use the alternative GAAP would be at a disadvantage in obtaining financing. Also, if some perceive the use of alternative GAAP as resulting in inferior, less reliable financial information, they might sue the companies for misleading users.

\section{CURRENT PROFESSIONAL INITIATIVES IN THE US}

In the US, there are two initiatives related to Big GAAP-Little GAAP that are of particular interest: one at the AICPA and one at the FASB.

\section{AICPA PRIVATE COMPANY FINANCIAL REPORTING TASK FORCE}

In May 2004, the AICPA Private Company Financial Reporting Task Force published a discussion paper, "Private Company Financial Reporting." Through this paper the Task Force wanted to:

... "ensure an informed dialogue" on the issue of the ability of "general purpose financial statements of private..., for profit entities" prepared in conformity with GAAP to meet the needs of users and to determine "whether or not the cost of providing ...GAAP financial statements is justified by the related benefits to private company constituents" (AICPA Private Company Discussion 2).

In furtherance of these aims, the Task Force conducted extensive research during 2004, including focus groups, a random survey, and an open on-line survey. Targeted constituents were: external stakeholders (primarily lenders, equity investors, and sureties), private company owners and financial managers, and public accounting practitioners. There were 3,709 responses (AICPA Task Force Report 5, 12). On February 28, 2005, the AICPA released the research results and the conclusions of the Task Force.

In summary, based upon the results, the Task Force concluded:

- $\quad$ There is a need for separate GAAP accounting for private companies to serve the needs of the users of those statements;

- $\quad$ Reporting with other comprehensive bases of accounting or GAAP with exceptions does not fulfill that need; and

- $\quad$ There is a need for a separate GAAP standards setting process for private companies (AICPA Task Force Report 6). 
When one delves into the research results in the "Task Force Report," however, it appears that the respondents are somewhat conflicted in their views. On the one hand, the respondents generally rated the importance of GAAP reporting and value of reporting under GAAP as moderately high to high (AICPA Task Force Report 14). Yet, on the other hand, the respondents viewed the "relevance/ decision usefulness" of many specific GAAP requirements with mixed results. The accrual basis of accounting and the cash flow statement generally garnered high ratings. Various more complex topics (share-based payments, variable-interest entities, intangibles, guarantees, leases, deferred taxes and post retirement/retirement plans) generally received lower ratings (AICPA Task Force Report 16).

Then, when pressed for the propriety of GAAP for smaller and/or privately held companies, these same respondents clearly supported differential GAAP based on size and/or public accountability. The surveys contained the following two questions:

- Would it be useful if the underlying GAAP reporting were different, in certain instances, for public vs. nonpublic companies?

- Would it be useful if the underlying GAAP reporting were different, in certain instances, based on the size of the company?

A significant portion, although not a majority of stakeholders, responded "yes" to both questions. A majority of owner managers responded "yes" to both questions. An overwhelming majority of CPA practitioners from all size CPA firms responded "yes" (AICPA Comparisons 55-60). Interestingly, it is also that group that indicated the greatest "challenge" to "keep current and up-to-date" on GAAP (52-54). (See the Appendix for a tabulation of selected survey results.)

The respondents seem to like the notion of GAAP, a set of standards which provides some degree of certitude and comparability in financial reporting. Yet it seems that they do not like the complexity of some GAAP rules. What many respondents appear to want is not GAAP but "GAAP Light."

The Task Force did not propose a vehicle for creating private company GAAP. It suggests a "cooperative effort" involving "key constituents of private company reporting" to determine who should develop GAAP and how it should be accomplished. It further recommends "outreach" to the FASB on these matters (AICPA Task Force Report 7).

\section{FASB SMALL BUSINESS ADVISORY COMMITTEE}

In 2003, the FASB established the Small Business Advisory Committee (SBAC):

...in an effort to obtain more active involvement by the small business community in the development of financial accounting and reporting standards. While the FASB has met with representatives of small businesses... establishment of a formal committee that provides the perspectives of this group will offer greater opportunity to share ideas, knowledge, and experience with the Board as well as with the other group members (FASB, Small Business Advisory Committee home page).

In its supporting materials for its May 2004 SBAC meeting, the FASB acknowledged that accounting has become more complex and that business transactions have become more complex. Markets must deal with issues related to such matters as derivatives, exit and disposal costs, variable interest entities, and debt and equity financial instruments. In addition the FASB also pointed out that it "has provided different measurement, presentation, disclosure, effective date, and transition requirements for nonpublic companies," citing issues involving share-based payment and disclosures about pensions (Batavick 19, 20).

In light of this changing and more complex market environment FASB wants to know:

- Do preparers have the necessary knowledge and skill to understand and implement new standards? 
- Do auditors have the necessary knowledge and skill to audit conformity with the standards?

- What are the users' needs from financial reporting?

- $\quad$ Are existing standards too complex?

- Would differential accounting impose extra cost?

- What should the FASB be doing to address the need of small businesses? (AICPA Task Force Report 2021).

At the meeting there was no consensus regarding GAAP and its application to smaller businesses. Members, however, had some interesting suggestions:

- $\quad$ FASB should allow nonpublic companies to report some items by disclosure only.

- $\quad$ FASB should allow nonpublic companies extra time for training and implementation of new standards.

- $\quad$ FASB should conduct more field tests.

- $\quad$ FASB could mitigate complexity of standards through the following:

$\circ \quad$ Write in Plain English;

- Codify the standards into a single source;

○ Provide implementation guides;

- Communicate industry implications; and

- Specify changes from existing standards

(FASB Minutes May 04 4, 5).

The SBAC met again December 2004. The executive director of the Financial Accounting Standards Advisory Council (FASAC) presented a summary of the annual FASAC survey of the Council and the FASB Board members. This year the SBAC members were also included in the survey. One question asked the participants to identify the five most important topics the FASB should take under consideration. The SBAC member responses indicated Differential Accounting Standards as the top priority (SBAC Agenda 12/01/04 43). In addition, "SBAC members overwhelmingly believe that the FASB should issue differential standards for certain entities" (SBAC Agenda 12/01/04 42). However, the individual views of the members span the range of arguments for and against Big GAAP-Little GAAP accounting, similar to those discussed earlier in the paper.

\section{INTERNATIONAL CONCERN WITH ACCOUNTING FOR SMALLER OR MEDIUM SIZED AND/OR PRIVATELY HELD COMPANIES}

Big GAAP-Little GAAP is an issue that concerns the accounting profession in other countries as well as the US. Outside the US, the accounting profession has, in general, made greater progress than in the US. The United Kingdom (UK) responded in 1997 with Financial Reporting Standards for Smaller Entities (FRSSE). By 2003, the International Accounting Standards Board had created an advisory committee for small and medium-sized entities (SME) to study the issues.

\section{UNITED KINGDOM (UK)}

According to Miller European Accounting Guide, the term GAAP is less well defined in the UK than in the US. The Accounting Standards Board (ASB), under the 1989 Companies Act, is the promulgator of GAAP in the UK. However, although "certain provisions are laid down by law and by established practice, a great deal [of accounting] is left to the discretion of company directors to decide..." (Miller).

As in the US, the vast majority of companies in the UK are small, private companies (Miller). Companies legislation in the UK generally defines small companies as private entities meeting at least two of the following criteria: annual turnover (revenues) of less than $£ 5.6$ million net, balance sheet total of less than $£ 2.8$ net, or less than 50 employees (ASB Amendment 131). In 1997, the ASB granted reporting relief to those companies with the creation of FRSSE. 
The basic measurement requirements in the FRSSE are the same as in other accounting standards (although with some slight simplifications), but many of the disclosure and presentation requirements of the other accounting standards have not been included in the FRSSE (ASB FRSSE Updated November 2004).

These standards have been:

... widely used and generally valued by practitioners...It is designed to help small companies to produce more useful and understandable information...A significant proportion of eligible companies-perhaps 40\%--take advantage take advantage of the of the exemptions FRSSE provides (Sleigh-Johnson 1,2).

The ASB is currently considering revision to FRSSE. Comments were due on February 22, 2005 to an Exposure Draft (ASB FRSSE Updated November 2004). This draft version is referred to as "A One-stop Shop FRSSE." It incorporates not only the accounting standards but "the relevant provisions of companies legislation" in one 208 page document (ASB Amendment 4).

An issue which complicates UK accounting is its membership in the European Union (EU). Effective January 1, 2005, use of the IASB's international accounting standards became mandatory for member countries for their consolidated accounts (European Parliament 3). In April 2004, the UK government said that companies not required to follow IASB standards could apply IASB standards or continue using UK standards. This would allow companies eligible to use FRSSE to continue to do so (Financial Times). But it also allows companies eligible to use FRSSE to use International Standards for SMEs as an alternative.

Isobel Sharp, partner with Deloitte and a member of the UK ASB and Chairman of its Committee on Accounting for Smaller Entities, is concerned about the availability of so many sets of accounting standards and their impact upon consistency in financial reporting (Sharp). Multiple sets of alternative standards would also affect comparability among private companies. In markets, where companies are pitted against each other in obtaining financing, multiple acceptable standards could lead to loss of useful information for decision making.

\section{IASB ACTIVITY}

In the European Union (EU), as in the US, there are millions of small and mid-sized entities. According to a literature review by Evans and di Pietra, research shows upward of $90 \%$ of all businesses in the EU are SMEs and they account for $50 \%$ to $99 \%$ of the employment in many EU countries (Evans 8). In those countries, unlike the US, there are requirements for all companies, whether public or private, to file financial statements using their countries' respective GAAP. Paul Pacter, IASB director of standards for small and medium sized firms, says:

...no developed economy requires these little companies - 5 million in Europe alone - to follow GAAP as rigorous as that of international or US standards, and that is not likely to change (Cheney 4).

Pacter wants the IASB to get ahead of the pack and:

...develop a simplified SME GAAP based on international standards that is suitable for use globally by millions of SMEs with statutory reporting obligation (Cheney 4).

In 2004, the IASB circulated a discussion paper, "Preliminary Views on Accounting Standards for Small and Medium-sized Entities," (IASB Preliminary Views) to gather views on a wide range of issues related to accounting for SMEs. The Board sought comments on broad issues such as whether IASB should make separate standards for SME and generally to whom such standards would apply. The Board also addressed detailed issues related to mandatory default or optional reversion to full International Standards (IFRS) under various circumstances (IASB Preliminary Views 1,2).

As described in the IASB Information for Observers of 12/04, an analysis of the letters, according to the SME committee, showed that two-thirds of the respondents believe that the International Financial Reporting 
Standards (IFRS) promulgated by the IASB are not "suitable" for all business entities. The comments indicate the belief that IFRSs are geared towards the benefit of the public capital markets and not the users of SME statements. Further, the IFRS are described as "unnecessarily complex" and "burdensome," casting doubt on the cost-benefit of complying with the IFRSs. Almost $90 \%$ of the respondents favor the IASB creating separate accounting standards for SMEs that meet the specific needs of their users. The rationale for continuing with IASB is to create consistency of accounting practice among eligible companies, short circuiting individual countries from developing their own standards for SME type entities (IASB Observers 12/04 1-2). With regard to the objectives of financial reporting relevant for SMEs, $88 \%$ of the commenters supported "high quality, understandable and enforceable accounting standards suitable for SMEs globally...focusing on meeting the needs of users, [and lessening the] reporting burdens SMEs" (IASB Observers 12/04 3).

At the December 2004 IASB meeting, based on the discussion paper comments and the recommendations of a subcommittee the Board reached some "tentative conclusions" which it "reviewed and affirmed" at its January 2005 meeting (IASB Update 1/05 3). The major conclusions were:

- $\quad$ The IASB should create SME standards;

- The standards would address financial reporting of "non-public accountability entities that have external users of their financial statements;"

- "National jurisdictions" would determine what entities would qualify for SME status;

- The SME standards would relate not only to "disclosure and presentation simplification" but to "recognition and measurement simplification" as well;

- If there is not a relevant SME standard for a "recognition or measurement issue," the IASB would require "mandatory fallback" to the relevant IFRS;

- $\quad$ An eligible SME entity must adopt all SME accounting standards and would be precluded from optional adoption of selected IFRSs;

- $\quad$ The SME standards would be categorized by topic not by the related IFRS; and

- $\quad$ More SME users should be added to the advisory group (IASB Update 12/04, 5).

Also at the January 2005 meeting, the Board "clarif[ied]...that the IASB Conceptual Framework should apply to all entities" and that "the Board should consider recognition and measurement simplifications for SMEs...based only on user needs and cost benefit" (IASB Update 1/05,3). Thus, in the view of the IASB, it is the user that is driving the SME project. Therefore, the Board has decided that the project:

...should focus on financial reporting by those non-publicly accountable entities (NPAEs) that publish general purpose financial statements for external users. Examples of such external users include owners who are not involved in managing the business, existing and potential creditors, and credit rating agencies (IASB Update 2/05 1).

In fact, The Board may consider barring small companies with no external users from using the SME standards (IASB Observers 2/05 6 and 3/05 3). Further, in light of the decision that the separate set of accounting standards would apply only to "non-publicly accountable entities," the new nomenclature for the initiative is IASB Non-Publicly Accountable Entities (Update 2/05, 1).

\section{WHERE DO WE STAND?}

What is clear from the Big GAAP-Little GAAP initiatives is that there is a significant demand both in the US and internationally for an alternative form of GAAP for companies that are not publicly traded. The factors driving this demand for a second GAAP are:

- The needs of users, and

- $\quad$ The cost of using current GAAP.

Although some have argued that a new standard setting body would be needed in order to provide adequate focus on the needs of smaller and/or privately held companies, the consensus seems to be that the current standard 
setters should be involved in the development of the new standards. Their involvement would provide instant authority for the standards as well as promote consistency with current accounting standards. Such an approach would, at least, partially counter arguments that Big GAAP-Little GAAP would result in Better GAAP-Lesser GAAP. The approach would also respond to the concern of confusion created by too many standards and standard setters.

Thus, in theory, the idea of an alternative GAAP promulgated by existing standard setters for smaller and/or privately held companies appears a reasonable solution to the Big GAAP-Little GAAP question. However, its implementation is rife with problems, some of which have been around since the first discussions of Big GAAP-Little GAAP in the 1970's.

The first issue is: To whom would Little GAAP be applicable? In the US, the Task Force survey indicated support for a public-private split and, secondarily, a large-small split. In the UK, FRSSE eligibility already relates to listed versus unlisted companies as well as to size. Defining the companies eligible for "Little GAAP" was a problem that held up development of differential accounting standards the first time around. And now the IASB is considering a new spin: only "nonpublicly accountable" entities who "publish general purpose financial statements for external users" would be eligible to use International Little GAAP(IASB Observer 3-05 3). It would exclude many previously included SMEs because they have no external users other than for tax or other regulatory filing. In our opinion, this limitation would undermine the progress made thus far on the Big GAAP-Little GAAP issue and would yet lead to another debate: Big GAAP-NPAE GAAP-Little GAAP. These SMEs with no existing external users also need a lower cost GAAP with authority and consistency.

A second issue is: Who should make Little GAAP? The direction the current initiatives are taking is towards the existing standard setters. This path, however, is not without its obstacles. Because the current standard setters traditionally focus on publicly traded companies, their views of the needs of the financial statement users of other types of entities may not be clear. Using organizations with closer ties to the nonpublic companies and the users of their financial statements might provide standards more responsive to their needs. In addition, the due process procedures of the current standard setters require long periods of time to accomplish their tasks. Other organizations might be able to develop more efficient due process procedures. However, there would be a time lag involved in setting up new standard setting bodies. Also, users of financial statements of companies in both groups (prepared under "Big GAAP" and "Little GAAP") would bear additional cost of learning to interpret multiple sets of GAAP.

A third issue is: What should Little GAAP be? All participants in the debate agree that, whatever the standards require, Little GAAP should meet the informational needs of the users. Some people hold that Little GAAP should simply be existing GAAP with fewer presentation and disclosure requirements and, perhaps, even some simplification on recognition and measurement. Others see Little GAAP as a simplified form of accounting based on the accepted conceptual frameworks that underlie existing GAAP.

We believe that the yet-to-be-developed principles based accounting may be an answer. There may be fewer disagreements about fundamental principles than there are about the detailed accounting and reporting requirements related to those principles. For example, most people would agree that assets on the Balance Sheet should not be overstated. And so the principle of recording an impairment in value when it occurs seems reasonable. But GAAP containing specific detailed calculations for determining the impairment might be excessive for smaller businesses. If the GAAP focused on the principle of recording impairment, perhaps there would be no need for a separate set of standards.

\section{CONCLUSION}

Although the Big GAAP-Little GAAP issue has been around since the 1970's and is currently being widely examined again, the reality is that we do not know enough to bring closure to this debate. One of the factors driving this demand supposedly is the needs of the users of the financial statements of small and/or privately held entities. Yet their needs are not clear. The AICPA Task Force findings are based on only 3709 survey responses, and the highest support for an alternative GAAP in those responses is from accounting practitioners, not users. The IASB conclusions result from only 117 comment letters. 
We need a broader base of knowledge to make better judgments. Perhaps the IASB survey and roundtables will provide more specific information about the needs of users. In addition, since the ASB has an eight year track record with FRSSE, an in depth study of the users of FRSSE statements might yield some concrete and viable ideas. We also need to consider what may be at the heart of these Big GAAP-Little GAAP initiatives. Is it really the needs of the users or is it the dissatisfaction of many accounting practitioners with the complex nature of current GAAP? When surveyed, it is that group that finds the greatest "challenge" to "keep current and up-to-date" with GAAP (AICPA Comparisons 52-54). We look forward to seeing continuing activity in both the US and internationally. We must always remember, whatever the outcome in this debate, what is important is that we meet the fundamental objective of accounting and financial reporting: to provide useful information for decision making.

\section{REFERENCES}

1. Accounting Standards Board, Amendment to Financial Reporting Standard for Smaller Entities 2004.

2. Accounting Standards Board, FRSSE, Updated November 2004.

3. American Institute of Certified Public Accountants, Codification of Auditing Standards, 2004.

4. American Institute of Certified Public Accountants, Private Company Financial Reporting Discussion Paper, 2004 http://www.aicpa.org/download/news/2004/Discussion_Paper_5-10-04.pdf

5. American Institute of Certified Public Accountants, Private Company Financial Reporting Task Force Report, 2005 http://www.aicpa.org/members/div/acctstd/pvtco fincl reprt/download/Report Draft Final.pdf

6. American Institute of Certified Public Accountants, Report of the Committee on Generally Accepted Accounting Principles for Smaller and/or Closely Held Businesses, 1976.

7. American Institute of Certified Public Accountants, This is the Title (forum discussion power point), 2004 http://www.aicpa.org/members/div/acctstd/pvtco_fincl_reprt/download/forum_discussion.ppt

8. American Institute of Certified Public Accountants, Private Company Financial Reporting Study-Random vs. Broad Outreach Key Comparisons, 2005. http://www.aicpa.org/members/div/acctstd/pvtco_fincl_reprt/index.htm

9. Batavick, George, Financial Accounting Standards Board, Handout for May 11, 2004, http://www.fasb.org/small_business_advisory_committee/sbac 05-11-04_handout.pdf

10. Cheney, Glenn, Differential Accounting: Problems \& Possibilities, Financial Executive, March/April 2004, http://accounting.smartpros.com/x42787.xml

11. Davidson, Sidney and Anderson, George, The Development of Accounting and Auditing Standards, Journal of Accountancy, May 1987.

12. European Parliament and Council, Regulation (Ec) No 1606/2002 of the European Parliament and of the Council on the Application of International Accounting Standards, July 2002 http://europa.eu.int/eurlex/pri/en/oj/dat/2002/1_243/1_24320020911en00010004.pdf

13. Evans, Lisa and di Pietra, Roberto, Comment on the IASB Discussion Paper 'Preliminary Views on Accounting Standards for Small and Medium-sized Entities' \#72, 2004.

14. Financial Accounting Standards Board, Agenda, SBAC December 1, 2004, http://www.fasb.org/small business advisory committee/sbac mtg handouts.shtml

15. Financial Accounting Standards Board, home page, http://www.fasb.org/small business_advisory_committee/

16. Financial Accounting Standards Board, minutes of the SBAC May 11, 2004, http://www.fasb.org/small_business_advisory_committee/sbac minutes.shtml

17. Financial Times Information, Financial Reporting: ASB Goes for One-Stop Shop, April 1, 2004.

18. International Accounting Standards Board, Preliminary Views on Accounting Standards for Small and Medium-sized Entities, 2004, http://www.iasb.org/uploaded files/documents/16 33 sme-ps.pdf

19. International Accounting Standards Board, Board Decisions on International Financial Reporting Standards Update, December 2004.

20. International Accounting Standards Board, Board Decisions on International Financial Reporting Standards Update, January 2005.

21. International Accounting Standards Board, Board Decisions on International Financial Reporting Standards Update, February 2005.

22. International Accounting Standards Board, Information for Observers, 12/04/05. 
23. International Accounting Standards Board, Information for Observers, 2/15/05.

24. Miller European Accounting Guide, Harcourt Brace and Company, 2000.

25. Sarbanes Oxley Act of 2002, http://corporate.findlaw.com/industry/corporate/docs/publ107.204.html

26. Sharp, Isobel, Financial Reporting: SMES-Vive la Difference? Financial Times Information, August 1, 2004.

27. Sleigh-Johnson, Nigel, Financial Reporting-Accounting Issues-In Defence of the FRSSE, Financial Times Information 2001, http://web.lexus-nexis.com/universe/

28. Swift, Richard, Financial Accounting Foundation 2003 Annual Report, http://www.fasb.org/annualreport/FAF_2003_AR.pdf

29. Wallace, Eric and Wortmann, Richard, Two GAAPs or Not Two GAAPs? That is the Question, Pennsylvania CPA Journal, Fall 2003.

http://www.picpa.org/asp/Journal/journal_article_details.asp?action=Normal\&ID=1061

\section{APPENDIX}

Tabulation Of Selected Items

From The AICPA Private Company Financial Reporting Task Force Survey Results

\begin{tabular}{|c|c|c|c|c|}
\hline \multicolumn{5}{|c|}{$\begin{array}{l}\text { Would it be useful if the underlying GAAP reporting were different, in certain instances, for public vs. non-public companies? Response: } \\
\text { Yes (AICPA Comparisons 55-57) }\end{array}$} \\
\hline Owner/Manager & Revenue $<5$ mill & \multicolumn{2}{|c|}{\begin{tabular}{|c|c|} 
& Revenue 5-25 mill \\
\end{tabular}} & Revenue > 25 mill \\
\hline Random Survey & $38 \%$ & \multicolumn{2}{|c|}{$50 \%$} & $49 \%$ \\
\hline Self Selected & $61.3 \%$ & \multicolumn{2}{|c|}{$66 \%$} & $67.8 \%$ \\
\hline & & & & \\
\hline Practitioners & $\leq 5$ partners & 6-10 partners & 11-20 partners & $>21$ partners \\
\hline Random Survey & $81.3 \%$ & $83 \%$ & $90 \%$ & $78 \%$ \\
\hline Self Selected & $86.7 \%$ & $85.3 \%$ & $90.8 \%$ & $66.5 \%$ \\
\hline External Stakeholders & Creditor Lender & \multicolumn{2}{|c|}{ Investor Venture Capitalist } & Surety Bonding \\
\hline Random Survey & $51 \%$ & \multicolumn{2}{|c|}{$50.5 \%$} & $39 \%$ \\
\hline Self Selected & $37.6 \%$ & \multicolumn{2}{|c|}{$53.7 \%$} & $28.6 \%$ \\
\hline
\end{tabular}

\begin{tabular}{|c|c|c|c|c|}
\hline \multicolumn{5}{|c|}{$\begin{array}{l}\text { Would it be useful if the underlying GAAP reporting were different, in certain instances, based on the size of the company? Respon } \\
\text { Yes (AICPA Comparisons 58-60) }\end{array}$} \\
\hline Owner/Manager & Revenue $<5$ mill & \multicolumn{2}{|c|}{ Revenue 5-25 mill } & Revenue > 25 mill \\
\hline Random Survey & $62 \%$ & \multicolumn{2}{|c|}{$57 \%$} & $59 \%$ \\
\hline Self Selected & $57.2 \%$ & \multicolumn{2}{|c|}{$51.4 \%$} & $47.2 \%$ \\
\hline Practitioners & $<5$ partners & 6-10 partners & 11-20 partners & $>21$ partners \\
\hline Random Survey & $71 \%$ & $73 \%$ & $77 \%$ & $65 \%$ \\
\hline Self Selected & $71.5 \%$ & $68.5 \%$ & $59.7 \%$ & $50.2 \%$ \\
\hline External Stakeholders & \multirow{2}{*}{$\frac{\text { Creditor Lender }}{69 \%}$} & \multicolumn{2}{|c|}{ Investor Venture Capitalist } & Surety Bonding \\
\hline Random Survey & & \multicolumn{2}{|c|}{$45.5 \%$} & $44 \%$ \\
\hline Self Selected & $39 \%$ & \multicolumn{2}{|c|}{$46.3 \%$} & $29.7 \%$ \\
\hline
\end{tabular}

\begin{tabular}{|c|c|c|c|c|}
\hline \multicolumn{5}{|c|}{$\begin{array}{l}\text { How challenging is it to keep current and up-to-date on GAAP standards? } \\
\text { Response: Extremely (AICPA Comparisons 52-54) }\end{array}$} \\
\hline Owner/Manager & Revenue $<5$ mill & \multicolumn{2}{|c|}{ Revenue 5-25 mill } & Revenue $>25$ mill \\
\hline Random Survey & $17 \%$ & \multicolumn{2}{|c|}{$19 \%$} & $27 \%$ \\
\hline Self Selected & $37.6 \%$ & \multicolumn{2}{|c|}{$33.7 \%$} & $37.4 \%$ \\
\hline Practitioners & $\leq 5$ partners & 6-10 partners & 11-20 partners & $\geq 21$ partners \\
\hline Random Survey & $41.1 \%$ & $49 \%$ & $50 \%$ & $74 \%$ \\
\hline Self Selected & $60.3 \%$ & $56.5 \%$ & $66.4 \%$ & $59.2 \%$ \\
\hline External Stakeholders & Creditor Lender & \multicolumn{2}{|c|}{ Investor Venture Capitalist } & Surety Bonding \\
\hline Random Survey & \multirow{2}{*}{$26 \%$} & \multicolumn{2}{|c|}{$24.8 \%$} & $24 \%$ \\
\hline Self Selected & & & & $22 \%$ \\
\hline
\end{tabular}

